This is the final peer-reviewed accepted manuscript of:

Tracing copper in the Cypro-Minoan script. 2016. Antiquity 90 (352), 1009-1021.

The final published version is available online at: http://dx.doi.org/10.15184/aqy.2016.66

Rights / License:

The terms and conditions for the reuse of this version of the manuscript are specified in the publishing policy. For all terms of use and more information see the publisher's website.

This item was downloaded from IRIS Università di Bologna (https://cris.unibo.it/)

When citing, please refer to the published version. 


\section{Tracing copper in the Cypro-Minoan script}

Silvia Ferrara ${ }^{1} \&$ Carol Bell $^{2}$

${ }^{1}$ Dipartimento Scienze dell'Antichità, Sapienza, University of Rome, Piazzale Aldo Moro 5 00185, Rome, Italy (Email: silvia.ferrara@uniroma1.it)

${ }^{2}$ Institute of Archaeology, University College London, 31-34 Gordon Square, London WC1H OPY, UK (Email: carol.bell@ucl.ac.uk)

Received: 13 March 2015; Accepted: 16 June 2015; Revised: 28 June 2015

$<$ LOCATION MAP $><6.5 \mathrm{~cm}$ colour, place to left of abstract and wrap text around $>$ The Cypro-Minoan script was in regular use on the island of Cyprus during the Late Bronze Age, and by Cypriot merchants overseas. Although still undeciphered, similar sign sequences inscribed on miniature copper 'oxhide' ingots and on associated clay labels may hold a clue to their meaning. They may indeed refer to 'copper' itself. The ingots were previously interpreted as votive offerings inscribed with dedications. Here it is suggested instead that these extremely pure copper miniatures were produced as commercial samples, and were marked with a brand denoting their high quality and provenance, such as 'pure Cypriot copper'.

Keywords: Cyprus, Late Bronze Age, writing, epigraphy, copper, ingot

\section{Tracing writing on Cyprus}

Cypro-Minoan writing, a syllabic script, was used on the island of Cyprus during the Late Bronze Age (c. 1550-1050 BC). Despite several attempts at decipherment, the language behind the script remains undetected (Masson 1974; Olivier 2007; Ferrara 2012). This conclusion makes all inferences on possible readings of texts highly tentative. Nonetheless, a close analysis of the inscriptions, and patterns of repeated sign-sequences, can point towards possible interpretations of subject matter in some of the texts, allowing a contextual understanding of how the script was used. It is attested at all urban sites in Late Bronze Age (LBA) Cyprus and the city of Ugarit in Syria; its period of maximum expansion can be assigned to the last centuries of the 
second millennium BC, until the very end of the LBA. The script is also found on a vast array of objects, metal vessels, clay balls, ivory objects and ceramics, usually represented by short inscriptions of a few sign-sequences.

The brevity of the texts, and the fact that the whole corpus comprises no more than 250 inscriptions, hinder all attempts at decipherment, but much can be inferred even without being able to read the script closely. Subject matters can be evinced with plausibility, if not with the full cogency of a decipherment. For instance, inscriptions on small spherical clay balls and ivory objects may record the names of individuals (Masson 1974; Ferrara 2012; Steele 2014). Equally, administrative texts are few and far between, but still represented to a limited extent (Smith 2002). Furthermore, the entire corpus of clay tablets in Cypro-Minoan comprises only ten examples, six from Cyprus (Karageorghis \& Kanta 2014: 110) and four from Ugarit (Yon 1999). The presence of tablets, in addition to other objects inscribed at Ugarit suggests strongly that a special relationship existed between Enkomi and Ugarit - two ports that face each other across $160 \mathrm{~km}$ of sea and that were important hubs in the trade of both copper and tin (Figure 1; Bell 2012).

$<$ FIGURE $1,13.5 \mathrm{~cm}$ colour >

Attempting to 'read without deciphering', we consider the possibility that one of the primary concerns of LBA Cypriots - the production and maritime trade of copper metal in ingot form-may have left tangible traces in the epigraphic evidence that can be detected with a degree of confidence. We therefore analyse a series of almost identical texts that recur on different types of objects from different locations where Cypro-Minoan is attested. The hypothesis we offer is that copper exported from the island as primary production from Cypriot ores (as opposed to recycled metal) may have borne a recognisable brand through inscriptions denoting its quality on miniature ingots (which may also have acted as samples), as well as on clay labels.

Wengrow (2008) recently investigated the role of commodity branding in prehistoric societies and a growing body of work has consequently considered whether this concept is applicable to the production and consumption behaviours of pre-industrial societies (Bushnell 2013). Prior to this, it was held that commodity branding was a phenomenon that arose from the economies of scale of the Industrial Revolution. Wengrow (2008) argued convincingly that early forms of commodity marking, such as sealing practices associated with the Urban Revolution in the fourth millennium BC, can shed light on the aspects such as quality, authenticity and 
ownership that are characteristics of modern brands when identifying mass produced goods. Arguably, the LBA was a period when abundant supplies of copper from mainland sources were also available to the main customers of Cyprus around the Mediterranean Basin, and a distinguishing mark denoting quality would have been desirable.

\section{Copper exports from Cyprus in the LBA}

The copper exports of Cyprus were crucial both to the island's prosperity during the LBA and its prominence in the widespread trading networks of the Eastern Mediterranean and Near East. Textual references to the availability of Cypriot copper on the mainland date back to the eighteenth century BC texts from Mari on the Euphrates where one text refers to copper from the 'mountain' of Alashiya, the ancient name for Cyprus (T.361; Knapp 1996: 18; Knapp et al. 2001).

The discovery of archaeological evidence of copper extraction on Cyprus from this period was comparatively recent due to destruction of ancient workings by continuous mining up to modern times. Politiko-Phorades, located in the northern Troodos foothills, was identified in 1996 as possibly being a primary smelting site. Subsequent excavations (Knapp et al. 2001) confirmed this, and radiocarbon dating, combined with well-stratified ceramics found in association with the metalwork, places Phorades in the early phase of the LBA (1650-1500 BC) (Knapp \& Kassianidou 2008).

The earliest evidence of metalworking at Enkomi comes from the Middle Cypriot III period (Stech 1982; Kassianidou 2013) in the so-called fortress area at the north of the site. This is the earliest evidence of metalworking from an urban site on Cyprus. Bronze-working was a major industry during the LBA, with this northernmost quarter containing the greatest concentration of metal workshops that span the entire occupation history of Enkomi, the earliest MC III layer being on bedrock (Dikaios 1971: 499; Courtois 1982). This is consistent in timescale with the textual references from Mari (Bell 2006: 78).

Much of the copper shipped from the island was in the form of oxhide ingots (which have been found from southern France to Mesopotamia and from the Danube to Thebes in Egypt), and lead isotope analyses of such ingots dating after $1400 \mathrm{BC}$ are consistent with a Cypriot origin (Gale 2011). Furthermore, not only do these ingots map to Cyprus, but specifically to the Apliki ore deposit in the north-eastern Troodos. 
Gale has also suggested that this mining area may have had a monopoly on providing copper for casting large oxhide ingots, while many copper-based artefacts from contemporaneous Cypriot sites were made from copper from other ore deposits around the Troodos. Perhaps Gale can be criticised for drawing conclusions on such specific origins for ingots (Pernicka 2014), but the technique remains useful for recognising ore bodies generated at different times.

Many oxhide ingots carry marks and generally scholars agree that these seem to resemble Cypro-Minoan more than other contemporaneous writing systems (Kaiser 2013: 45). Kaiser has noted that of the sites known to have contained half ingots or fragments larger than this, at least 245 bear marks: approximately 58 per cent of the corpus. With few exceptions, however, these full-sized ingots do not bear marks that can unequivocally be identified as Cypro-Minoan.

\section{Branding the miniature copper ingots}

There are six miniature ingots from Enkomi and half of one from Mathiatis, four of which are inscribed in Cypro-Minoan (Figure 2). XRF spectrometry has demonstrated that they are all made of virtually pure copper, rather than bronze, and contain no trace of tin (Giumlia-Mair et al. 2011).

<FIGURE 2, $6.5 \mathrm{~cm}$ greyscale>

Since the 1950s, the function of these miniature ingots has been consistently interpreted as votive (Catling 1971; Karageorghis \& Masson 1971; Masson 1971; Knapp 1986; Papasavvas 2009; Giumlia-Mair et al. 2011; Kaiser 2013), with inscribed specimens carrying dedications to deities. This was based on the assertion that the ingot symbolism and copper production were interpreted as connected with religious practices (Catling 1971 for the Ingot God figurine), which came under the protection of gods worshipped in the sanctuaries of manufacturing cities (Knapp 1986). However, the association of the miniature ingots with cult, at Enkomi at least, is tenuous (Webb 1999). Only two contexts can support an, albeit vague, ritual association. The contexts in which the other specimens were found are unequivocally domestic. Their votive function is, therefore, to be questioned.

If the contextual association of the objects does not yield incontrovertible indication of their purpose, a close analysis of the texts on the inscribed ingots may help to advance possible inferences. This synergic perspective, one that combines archaeological and epigraphic evidence, is essential to developing the study of any 
undeciphered script. Indeed, this approach has met with remarkable success in recent times for ancient writing in general (e.g. Houston 2004). Three examples of miniature ingots from Enkomi bear recognisable inscriptions (inv. 1936/Vi-19/1, \#\#174 in Olivier 2007 and inv 53.2, \#\#175, inv. 53.3 \#\#176 in Ferrara 2012), that is, inscriptions of two or more consecutive associated signs diagnostic of the CyproMinoan repertoire. A fourth example from Enkomi, inv. 1995 (Dikaios 1971: 691; Giumlia-Mair et al. 2011: 14, fig. 2.2) bears only one sign, and thus cannot be taken to be an inscription stricto sensu (which explains why it was excluded from the extant corpora of C-M texts). However, the single sign on this specimen can be recognised as a rotated sign 23 in the Cypro-Minoan signary, which corresponds in shape to $\{$. This sign happens to be attested on the other miniature ingots, also in an isolated position. As can be observed in Figure 3, the pattern of epigraphic regularity on the first three ingots is interesting.

<FIGURE 3, $13.5 \mathrm{~cm}$ greyscale>

Ingots \#\#174 and \#\#176 share the same signs, separated by the usual division marker, which singles out sign-sequences. Single signs are regularly attested in the Cypro-Minoan corpus, most notably on a large number of inscribed clay balls and other high-status paraphernalia, such as ivory objects, metal bowls, etc. (see Figure 4 for a full list).

\section{$<$ FIGURE 4, $13.5 \mathrm{~cm}$ greyscale>}

Ingot \#\#175 bears a sequence of $1+1$ words with the first sequence identical to those attested on the other two ingots, albeit without the division marker. The first two signs on this ingot are spaced out as equally as the rest of the signs in the remainder of the inscription, with no evident gap between them. This implies that we cannot argue that a separating space was intended between sign $102(\ddot{Y})$ and sign 23 ( $\{$ ), in substitution for the vertical dividing bar. Are we, therefore, to assume that the same sequence was recorded on the three ingots, or, conversely, that the beginning of the text on \#\#175 is semantically different? There is evidence to support the former hypothesis.

It is worth mentioning that the reading of the inscriptions on the ingots, and their exact function, are controversial. It has been stated that:

"the first sign on the three miniature ingots from Enkomi coincides with the second sign, after a vertical bar, inscribed on the two bronze ring-stands from Myrtou-Pigades [...]. These artifacts were found in a sanctuary, so their 
inscriptions are most probably dedicatory. This can be taken as indirect evidence for the votive character of the miniature ingots" (Giumlia-Mair et al. 2011: 17).

We can claim with a certain degree of confidence that this is not the case, as the two ring-stands from Myrtou-Pigades bear different inscriptions from the ones incised on the ingots (\#\#184 and \#\#185 in Olivier 2007: 257-58 and Ferrara 2013: 93-94, 23031). The inscriptions on the two ring-stands are identical, namely äł $\tilde{A}$... and ä Ã... (038-104-101). Noteworthy is the fact that the second ring-stand, \#\#185, does not have the separation marker seen in the first, which, again, offers an intriguing parallel for the missing separator on ingot \#\#175, and further reinforces the possibility that typologically identical objects with almost identical texts, distinguished only by the presence or absence of a word-divider, are intended to bear the same message.

Despite the regularity in indicating word-division in Cypro-Minoan, several instances of missing division markers can be observed. Figure 4 records only a few, but more can be detected and restored throughout the corpus (see \#\#042, \#\#054, \#\#078, \#\#185; Olivier 2007). Therefore, by analogy, it would not be counter-intuitive to venture into restoring a separation marker between the first two signs on \#\#175. This would harmonise the epigraphic evidence on the ingots and help further to make sense of their significance as a set. But, as will become apparent below, a striking parallel strengthens this inference significantly.

\section{Traces of copper from Ugarit}

As already mentioned, Ugarit in Syria is the principal overseas find-spot of CyproMinoan inscriptions, where eight examples have been found. The mini-corpus of texts includes four tablets that were found either in, or in the proximity of, houses of merchants known from Ugaritic and Akkadian archives (van Soldt 2000). The house of Urtenu yielded a label inscribed in Cypro-Minoan (\#\#210, RS 94.2328; Yon 1999; Olivier 2007; Ferrara 2013). As shown in Figures 3 and 5, the text on the label is identical to the first sequence found on miniature ingot \#\#175.

$<$ FIGURE 5, 6.5 cm colour>

Similarly, on this object, the expected division marker between the two signs, $\ddot{Y}\{(102-23)$, is missing, although in its place there is an evident gap, with signs appearing intentionally spaced out on the label. Therefore, we can postulate that they may either have been separated by a division marker, which could be restored, or else 
that they were clearly recognisable as two distinct signs that were not strictly consecutive (that is, part of one sign-sequence). Typologically, the label does not fit into the classes of labels normally found at Ugarit (van Soldt 1990) and the likelihood is that it was not inscribed in Syria, but sent from Cyprus, attached to, or identifying, commodities intended for export. This can be inferred from the characteristics of the signs, which resemble more closely the Cypro-Minoan varieties found on Cyprus than the highly idiosyncratic writing on the remainder of the inscriptions from Ugarit, which were most likely written in situ by scribes not particularly familiar with Cypriot writing (Ferrara 2012).

There is another such label (\#\#211, RS. 99.2014, quoted in passing, in Yon 1999; Olivier 2007; Ferrara 2013), which is very similar in format and sign-shapes to label \#\#210, although the inscription is different, as it probably reads òœ (052-107064, the text is damaged). Although the quantity of evidence is limited, a plausible explanation is that such labels fulfilled the same function as marks of direct Cypriot provenance.

Could the (almost) identical texts outlined in Figure 3 refer to copper in some way? And if so, can we take the argument a step further and narrow down the possible message carried by the inscriptions? Can the texts themselves help venture further into the significance of the miniature ingots as exclusive, prerogative objects produced by the Cypriots? Before we turn to these admittedly challenging questions, a lexical excursus may inform our investigation.

\section{Philological traces of metals}

Semitic languages, such as Ugaritic and Hebrew, share the trait of not adopting a lexical distinction between 'copper' and 'bronze'. This can be extended to Mycenaean and historical Greek use, where $k a-k o$ and $\chi \alpha \lambda \kappa o ́ \varsigma$ indicate interchangeably both materials (despite scholarly resistance in accepting the fact that $k a-k o$ refers to copper; see Muhly 2009). This applies to Akkadian as well, but the terminology is more complex, as Akkadian distinguishes between copper (w)erû and bronze siparru, but the terms do intersect (Zaccagnini 1971), and also to Egyptian, where the word for copper and that for bronze coexisted. It is interesting to note that, lexically, the terms for bronze are late or restricted to special regions. Incidentally, $k a-k o$ points to a nonIndo-European source, since Proto Indo-European does not tolerate a root with a voiceless and an aspirated stop. In Hittite, the Sumerogram ZABAR is used, but the 
phonetic equivalent used is unknown (Mallory \& Adams 1997). That the potential confusion engendered by this lack of differentiation may arise in the early texts is hardly surprising, since copper and bronze are not easily distinguished by eye (Moorey 1994; Muhly 2009). This point proves relevant for our purposes.

Although we cannot speculate on the language(s) spoken by the LBA Cypriots, it seems reasonable to assume that a word for copper was in common use, and possibly written down in Cypro-Minoan. It has been suggested that the name of the island as 'Kypros' may descend from Hurrian *kab/p (kabali), meaning 'copper' (Duhoux 2003; Knapp 1996: 11-13), which later, through Latin cuprium 'Cypriot', came to mean the raw material found on Cyprus. In this case, the word for copper would have no correlation with the name of the island as it was known during the Bronze Age, a name that was transmitted through sources that are not directly Cypriot. In the Amarna letters and in Ugarit correspondence of the LBA, both written in Akkadian cuneiform, Cyprus is invariably referred to as Alashiya (Knapp 1996).

Turning to the inscriptions on the ingots and on the Ugarit label, if we accept that the first two signs on them record the same message, we could speculate on its meaning in the broader context of the functionality of the ingots. The ingots are Cypriot, and are made of refined copper - more so than even the very pure copper of full-sized oxhide ingots (Kassianidou 2009; Giumlia-Mair et al. 2011). This suggests a symbolic importance that had close ties with the production process and demand for objects containing pure copper coming from the island. Cypriot producers would have wished to make such a distinction clear, in order to obtain the highest value, when dealing with potential customers. To achieve this, what better strategy could have been adopted than marking provenance and quality on the ingots? Could this be an early form of brand or trademark?

It is instructive to consider how industrial metals are sold nowadays on the London Metal Exchange. These metals are priced and delivered according to their 'brand', defined as a mark or name identifying the smelter, refiner, semi-fabricator or steelworks that produced the metal. In primary metals (those that have been smelted directly from ore, rather than from recycled scrap), this is often associated with a full chemical analysis.

Returning to the inscriptions, several analyses of the palaeography of the Cypro-Minoan inscriptions, note that sign $102 \ddot{Y}$ invariably appears in initial position within a sign-sequence (Ferrara 2012, Appendix 5; Olivier 2007: 474-76). In an open 
syllable internal structure, as is the case for Cypro-Minoan, such a characteristic highlights the presence of a single vowel being recorded. It has been suggested that sign $102 \ddot{Y}$, being the sign most frequently found in initial position, could record the vowel /a/ (Masson 1974). This sign appears very similar to the sign used for the same vowel both in Linear B, $\square$, and in the Cypriot Syllabary of the first millennium, $\square$. Could this point to a reference to Alashiya (Cyprus), abbreviated at the beginning, to indicate the origin of the object? And further on, the second syllable recorded on the ingots and the label from Ugarit, sign 23 \{, is similar to the sign for the syllable /ti/ in the Linear B script, $\square$. The sign for the same syllable in the Cypriot Syllabary, $\square$, could be a local Cypriot development, in direct trajectory from Cypro-Minoan. If this is correct, then a case could be made for another abbreviation, for the Cypriot word for 'copper', a word possibly starting with /ti/. Could this be an adapted loan of the

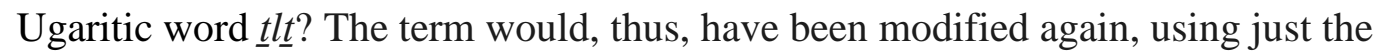
beginning of the word.

Caution must be exercised when proposing such hypotheses before they can be tested against more substantial attestations. As is well known, similarity in the shape of signs is never an unassailable method for establishing sound values. By this line of reasoning, we could claim that the similarities in the signs for the syllable /ti/ in known scripts may not point to the same phonetic realisation in homomorphic sign 23 \{. Moreover, the interpretation we have just proposed should work for all other attestations of the isolated sign 23 \{. This becomes more difficult to prove if such occurrences are on objects that may not have anything to do with copper specifically (see the same attestations of sign $102 \ddot{Y}$ and sign 23 \{, found in isolated position on the ivory pipe \#\#161, Figure 4). We cannot, therefore, rule out the possibility that both signs have been used as abbreviations for other words, or that they may be logograms. We may never discover the word for 'copper' in ancient Cypriot, but the fact that the material of which the miniature ingots are made would be part of the message to be conveyed on them, as a trademark and precise assertion of its purity, remains a tantalising proposition. If, as postulated above, a rotated sign 23 is also attested on miniature ingot 1995, then all specimens of the miniature ingots bear the same 'brand' and this congruence of signs in the whole repertoire of pure copper objects points to the same statement: these objects are made of 'pure Cypriot copper'.

With this in mind, we would like to propose a new interpretation that avoids the necessity to invoke a votive function for the ingots and a dedicatory one for their 
inscriptions. These objects may not have a practical use as miniature versions of the full-scale functional objects they mimic, but they do have an intrinsically symbolic one. The function of pure copper is never utilitarian. But in selling it abroad, Cypriots must have been aware of how marking its exclusive quality 'as 100 per cent copper' would differentiate it from similar objects, which the naked eye could mistake for bronze. Put in modern terms, marking the miniature ingots made of Cypriot copper branded them as pure and created a unique selling proposition. Could the marked miniature ingots have acted as a specific and exclusive form of sample material for Cypriot intermediaries to show to the customers who acquired the tons of full-sized oxhide ingots that were exported from the island during the LBA?

\section{Marking copper in the Mediterranean}

Now that a reading of these inscriptions, albeit speculative, has been proposed, it may be worth integrating it with the more general activity of marking normal-sized oxhide and bun ingots. Marks on these typologies of objects are impressed, incised or chiselled, and are attested on at least half of the corpus of oxhide ingots from several sites in the Mediterranean, in notable quantities from the Uluburun and Cape Gelidonya shipwrecks. In analysing the morphology of these marks, it becomes apparent that their relation to the Cypro-Minoan script is tenuous, despite a general tendency to assume it as a working hypothesis (Amadasi Guzzo 2009; Kaiser 2013).

As already brought to light by Hirschfeld in relation to the practice of marking pottery, the shapes of the signs present on both ceramics and ingots, which are to an extent shared, are basic and pervasive in all marking systems of the Mediterranean, defined as 'simple marks that cross cultural boundaries' (Hirschfeld 1999: 109, 249). Their relation to language notation is problematic, and we should discount any intentional recording of morphological features, even in abbreviated form. As a viable parallel, it can be noted that Greek lead ingots from Laurion often were stamped with non-alphabetic trademarks (Bass 1967). Therefore, it is worth stressing the fact that the marks on the normal-sized ingots have nothing to do with Cypro-Minoan or with any script that records language.

If their correlation to proper writing is to be discounted, the interpretation of their function remains equally obscure. The scholarship on the topic has grappled with this problem without reaching cogent results (Hirschfeld 1999; Kassianidou 2003; Amadasi Guzzo 2009; Kaiser 2013). The marks may have been used to record 
processes, such as shipping information, and may have been related to the producers, harbours of departure, addresses for delivery, etc. (Kaiser 2013). Some of them may also point to the source of metal, be it a mine, mine-owner, state official or guild. This has been proposed for the marks that Bass calls 'primary', namely those impressed into the metal while it was soft (Bass 1967: 72), as opposed to those incised at a later stage, post-manufacture.

This brief excursus on oxhide ingot marks is helpful because it can shed more light on the significance of the miniature ingots. From a macro perspective, if the marks indicate manufacture, whether a stage in the production, shipping or delivery, the inscriptions on the miniature specimens may be more suggestive, and recognisable, in the statements they make, because they are made in a specific language and script. They may be, in other words, testimonials of value and provenance of the material of which they are made. In this light, the miniature ingots in themselves will act as samples, and the inscriptions as reinforcing statements.

It is interesting to note that ingots in Roman times bore more information than any other ancient body of such objects. Inscriptions on lead 'pigs' and 'bun-shaped' copper ingots from Roman Britain and Gaul were stamped with personal names or with the letters socio(rum) Romae. Cast mould marks on lead ingots read socior(um) Lut(udarensium) Brit(annicum) ex arg(entariis), i.e. 'British lead from the silver mines of the socii at Lutudarum', which is a Derbyshire lead-mining area (Hirt 2010). Most mould marks on lead ingots dated to the Principate provide the personal names of individuals, in abbreviated form, as do those on ingots found on shipwrecks from the Balearics, southern Gaul and Corsica (Domergue 1990). For the Roman ingots, the application of cold stamps, holes and numerals can be explained, but the role of the individuals is more difficult to identify. There tends to be a genitive of the personal name, possibly a possessive indicating ownership. The origin is indicated, either by adjective or by preposition. These may name the initial owner of the ingot at the time it was cast (Hirt 2010: 283). Ingots were, in effect, personalised.

This parallel could explain a section of one of the inscriptions of the ingots that we have not yet treated, the sign-sequence on the Enkomi ingot no. 53.3, \#\#175. This sequence, $\ddot{Y} a \dot{a} \div\{(102-?-23-?-23)$ is only attested here. Two of the signs (the second and fourth) are also only attested here. What is significant is the fact that the last sign appears in word-final position often in the corpus of inscriptions. It has been suggested elsewhere that it may function as a possessive suffix (Masson 1974, Ferrara 
2012). If this is correct, it would point to the possibility that a personal name may be recorded, in addition to and after the abbreviated signs denoting origin and purity of material.

\section{Writing as 'branding'}

Overall, the miniature ingots, together with the inscriptions, appear to function within a value system that understands the desirability of pure Cypriot copper. In contrast to what has been suggested in the past, the likelihood is that they did not represent votive religious paraphernalia, and the texts they bear need not have been dedications to unidentifiable deities. The, admittedly circumstantial, evidence we have presented here strongly suggests that the miniature ingots functioned as branded tokens of quality and as samples of original production. In this capacity, they assisted in the process of convincing consumers of the desirability of acquiring pure Cypriot copper.

We cannot speculate that the miniature ingots were intended to be sold, but the label bearing the same inscription found abroad probably arrived at its destination through commerce. Consumers will consider purity, quality and provenance as factors when selecting commodities, and the wider cultural value of pure Cypriot copper was recognised throughout the Eastern Mediterranean. All full-sized oxhide ingots after $1400 \mathrm{BC}$ are argued to be consistent with production from Cypriot ores. By the end of the LBA, this trade became commoditised. The placement of specific writing on individual, and individualised, objects generated an element of added value, for further exotic appeal. It is not coincidental, perhaps, that Cypro-Minoan was chosen as the script to carry this message.

Unlike tin, copper is relatively common in nature and marking Cypriot copper with an attestation of its quality and provenance would differentiate the commodity, enabling Cypriot producers and their intermediaries to attain the best value for their metal. Last, but not least, in an age when recycling of copper and bronze was well known, might these marks also have indicated that the copper was the product of primary smelting of ore-directly from the mine - in the way that primary metal is still marked and assayed today?

\section{References}

Amadasi Guzzo, M.G. 2009. Marks on Central Mediterranean copper ingots, in F. Lo Schiavo, J.D. Muhly, R. Maddin \& A. Giumlia-Mair (ed.) Oxhide ingots in the 
Central Mediterranean: 431-35. Rome: A.G. Leventis Foundation.

Bass, G.F., P. Throckmorton, J. Du Plat Taylor, J.B. Hennessy, A.R. Shulman

\& H.G. BuchHOLz. 1967. Cape Gelidonya: a Bronze Age shipwreck. Transactions of the American Philosophical Society 57: 1-177. http://dx.doi.org/10.2307/1005978

BELL, C. 2006. The evolution of long distance trading relationships across the LBA/Iron Age transition on the northern Levantine coast: crisis, continuity and change (British Archaeological Reports international series 1574). Oxford:

Archaeopress.

- 2012. The merchants of Ugarit. Oligarchs of the LBA trade in metals?, in V.

Kassianidou \& G. Papasavvas (ed.) Eastern Mediterranean metallurgy and metalwork in the second millennium BC, proceedings of a conference in honour of James D.

Muhly, Nicosia $10^{\text {th }}-11^{\text {th }}$ October 2009: 180-87. Oxford: Oxbow.

BushnelL, L. 2013. The socio-economic implications of the distribution of juglets in the Eastern Mediterranean. Unpublished PhD dissertation, University College London.

Catling, H.W. 1971. A Cypriot bronze statuette in the Bomford Collection, in C.F.A. Schaeffer (ed.) Alasia I. Publié à l'occasion de la XXe campagne de fouilles à Enkomi-Alasia (1969): 15-32. Paris: Missions archéologiques d'Alasia IV.

Courtois, J.-C. 1982. L'activité métallurgique et les bronzes d'Enkomi au Bronze Récent (1650-1100 avant J.-C.), in J. Muhly, R. Maddin \& V. Karageorghis (ed.) Early metallurgy in Cyprus 4000-500 BC: 156-75. Nicosia: Pierides Foundation in collaboration with the Department of Antiquities Republic of Cyprus.

DikAIOS, P. 1971. Enkomi: excavations, 1948-1958, volume II. Mainz-am-Rhein: von Zabern.

Domergue, C. 1990. Les mines de la Peninsule Iberique dans l'antiquité romaine (Collection de l'École française de Rome 127). Rome: École française de Rome.

Duhoux, Y. 2003. Un nom du 'bronze' en linéaire A? Cretan Studies 9: 17-26.

FERrARA, S. 2012. Cypro-Minoan inscriptions: analysis. Oxford. Oxford University Press.

- 2013. Cypro-Minoan inscriptions: corpus. Oxford: Oxford University Press.

GALE, N. 2011. Copper oxhide ingots and lead isotope provenancing, in P. Betancourt \& S. Ferrence (ed.) Metallurgy: understanding how, learning why: studies in honor of James D. Muhly: 213-19. Philadelphia (PA): INSTAP Academic Press. 
GiUmlia-MAir, A., V. KASSIANIDOU \& G. PAPASAVVAS. 2011. Miniature ingots from Cyprus, in P. Betancourt \& S. Ferrence (ed.) Metallurgy: understanding how, learning why: studies in honor of James D. Muhly: 11-19. Philadelphia (PA): INSTAP Academic Press.

Hadjisavvas, S. 1989. A Late Cypriot community at Alassa, in E. Peltenburg (ed.) Early society in Cyprus: 32-42. Edinburgh: Edinburgh University Press.

HIRSCHFELD, N. 1999. Potmarks of the Late Bronze Age Eastern Mediterranean. Unpublished PhD dissertation, University of Texas at Austin.

HIRT, A.M. 2010. Imperial mines and quarries in the Roman World. Organizational aspects $27 B C-A D$ 235. Oxford: Oxford University Press.

http://dx.doi.org/10.1093/acprof:oso/9780199572878.001.0001

Houston, S.D. (ed.). 2004. The first writing. Script invention as history and process. Cambridge: Cambridge University Press.

KAISER, A. 2013. Copper oxhide ingot marks: a database of comparative analysis. Unpublished MA dissertation, Cornell University.

Karageorghis, V \& A. Kanta. 2014. Pyla-Kokkinokremos. A late $13^{\text {th }}$ century fortified settlement in Cyprus. Excavations 2010-2011. Uppsala: Astrom.

Karageorghis, V. \& E. Masson. 1971. Un bronze votif inscrit (modèle de foie ou de rein?) trouvé à Kition en 1970. Studi Ciprioti e Rapporti di Scavo 1: 237-47.

KAssianidou, V. 2003. The trade of tin and the island of copper, in A. Giumlia-Mair and F. Lo Schiavo (ed.) The problem of early tin. Acts of the XIV UISPP Congress. Liège 2-8 September 2001 (British Archaeological Reports international series 1199): 109-19. Oxford: Archaeopress.

- 2009. Oxhide ingots in Cyprus, in F. Lo Schiavo, J.D. Muhly, R. Maddin \& A. Giumlia-Mair (ed.) Oxhide ingots in the Central Mediterranean: 41-81. Rome: A.G. Leventis Foundation.

- 2013. The production and trade of Cypriot copper in the Late Bronze Age. An analysis of the evidence. Pasiphae 7: 133-46.

KNAPP, A.B. 1986. Copper production and divine protection: archaeology, ideology and social complexity on Bronze Age Cyprus. Gothenberg: Astrom.

- 1996. Near Eastern and Aegean texts from the third to the first millennia BC (Sources for the History of Cyprus 2). Altamont (NY): Greece/Cyprus Research Center. 
KNAPP, A.B. \& V. KASSIANIDOU. 2008. The archaeology of Late Bronze Age copper production: Politiko Phorades on Cyprus, in Ü. Yalçin (ed.) Anatolian metal IV: Frühe Rohstoffgewinnung in Anatolien und seinen Nachbarländern. Der Anschnitt, (Veröffentlichungen aus dem Deutschen Bergbau-Museum 157): 135-47. Bochum: Deutsches Bergbau-Museum.

KNAPP, A.B., V. KASSIANIDOU \& M. DonNELly. 2001. Copper smelting in Late Bronze Age Cyprus: the excavations at Politiko Phorades. Near Eastern Archaeology 64(4): 204-10. http://dx.doi.org/10.2307/3210830

MALLORY, J.P. \& D.Q. ADAMS. 1997. Encyclopedia of Indo-European culture. London: Fitzroy Dearborn.

Masson, E. 1974. Cyprominoica. Répertoires. Documents de Ras Shamra. Essais d'interpretation (Studies in Mediterranean Archaeology 31.2). Gothenberg: Astrom. Masson, O. 1971. Deux petits lingots de cuivre inscrits d'Enkomi (1953), in C.F.A. Schaeffer (ed.) Alasia I. Publié à l'occasion de la XX campagne de fouilles à Enkomi-Alasia (1969): 449-55. Paris: Missions archéologiques d'Alasia IV. MoOREY, P.R.S. 1994. Ancient Mesopotamian material and industries: the archaeological evidence. Oxford: Oxford University Press.

Muhly, J. 2009. Oxhide ingots in the Aegean and in Egypt, in F. Lo Schiavo, J.D. Muhly, R. Maddin \& A. Giumlia-Mair (ed.) Oxhide ingots in the Central Mediterranean: 17-39. Rome: A.G. Leventis Foundation.

OLIVIER, J.P. 2007. Edition holistique des textes chypro-minoens. Pisa-Roma: Fabrizio Serra.

Papasavvas, G. 2009. The iconography of the oxhide ingots, in F. Lo Schiavo, J.D. Muhly, R. Maddin \& A. Giumlia-Mair (ed.) Oxhide ingots in the Central Mediterranean: 83-132. Rome: A.G. Leventis Foundation.

PERNICKA, E. 2014. Provenance determination of archaeological metal objects, in B.W. Roberts \& C. Thornton (ed.) Archaeometallurgy in global perspective: methods and syntheses: 239-68. New York: Springer. http://dx.doi.org/10.1007/978-1-46149017-3_11

SMITH, J.S. 2002. Problems and prospects in the study of script and seal use on Cyprus in the Bronze and Iron Ages, in J.S. Smith (ed.) Script and seal use on Cyprus in the Bronze and Iron Ages: 1-47. Boston (MA): Archaeological Institute of America. 
STECH, T. 1982. Urban metallurgy in Late Bronze Age Cyprus, in J. Muhly, R.

Maddin \& V. Karageorghis (ed.) Early metallurgy in Cyprus 4000-500 BC: 105-17.

Nicosia: Pierides Foundation in collaboration with the Department of Antiquities Republic of Cyprus.

SteEle, P. 2014. The mystery of the ancient Cypriot clay balls. British Academy Review 24: 60-63.

VAN SOLDT, W.H. 1990. Labels from Ugarit. Ugarit Forschungen 21: 375-88.

- 2000. Private archives at Ugarit, in A.C.V.M. Bongenaar (ed.) Interdependency of institutions and private entrepreneurs. Proceedings of the Second Mos Symposium: 229-45. Leiden: Nederlands Historisch-Archaeologisch Instituut te Istanbul.

WEBB, J.M. 1999. Ritual architecture, iconography and practice in Late Bronze Age Cyprus. Gothenberg: Astrom.

Wengrow, D. 2008. Prehistories of commodity branding. Current Anthropology 49:

7-34. http://dx.doi.org/10.1086/523676

Yon, M. 1999. Chypre et Ougarit à la fin du Bronze Récent. Report of the Department of Antiquities, Cyprus: 113-18.

ZaCCAGNini, C. 1971. La terminologia accadica del rame e del bronzo nel I millennio. Oriens Antiquus 10: 123-44. 
Figure captions

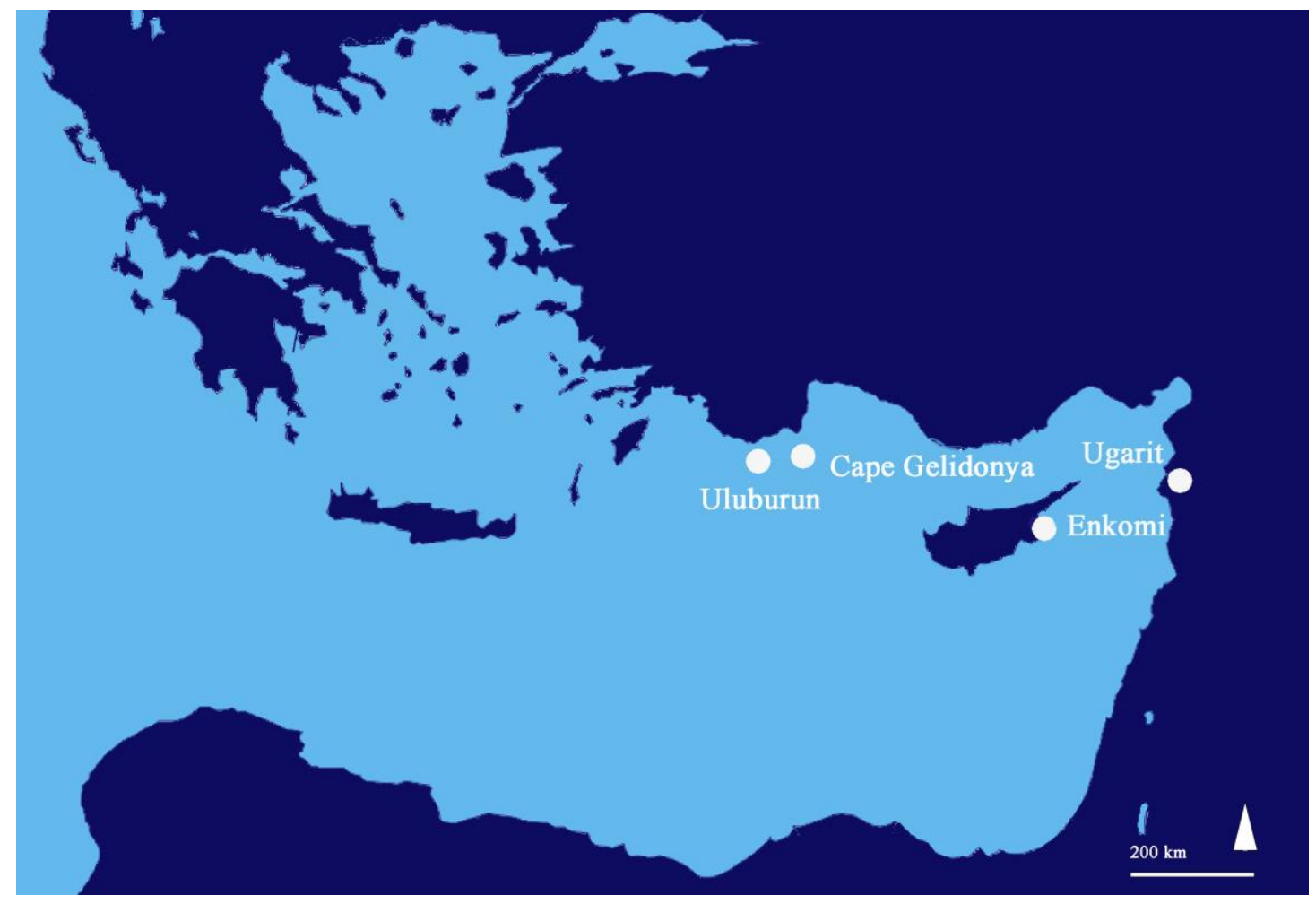

Figure 1. The Eastern Mediterranean, showing locations mentioned in the text. 

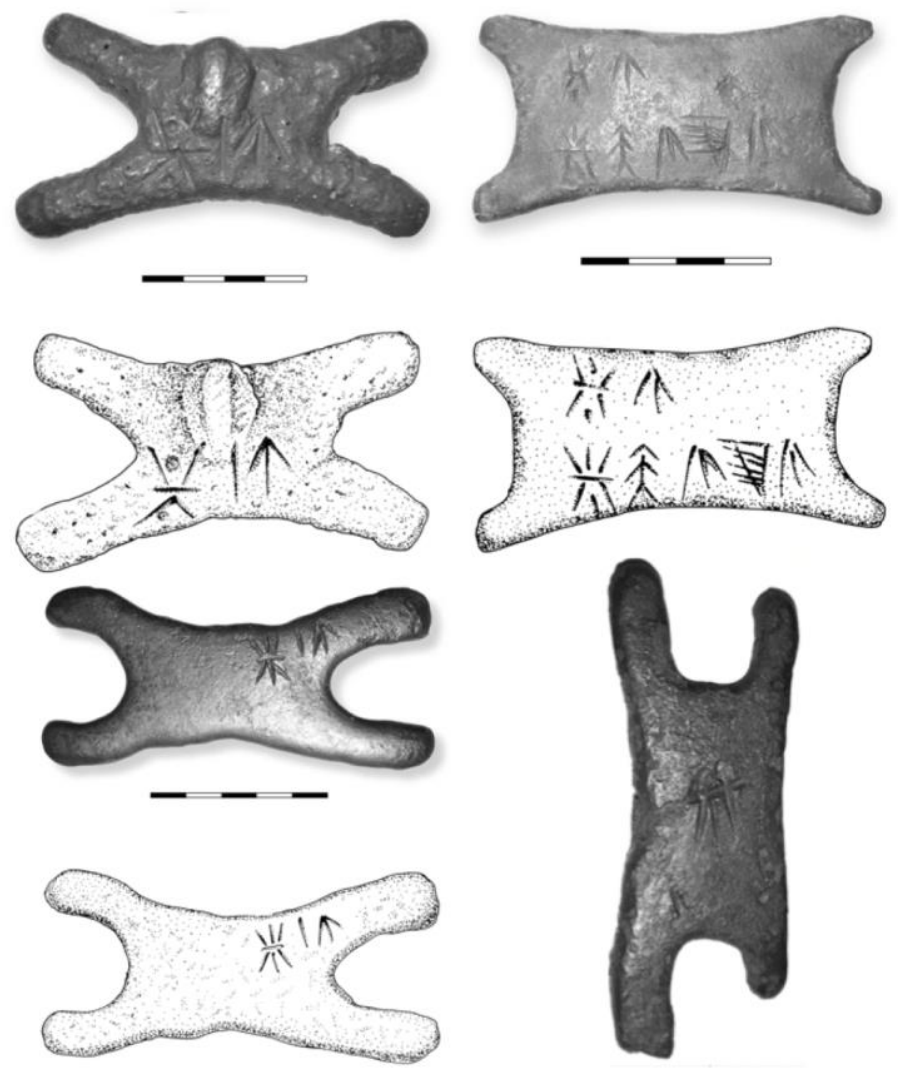

Figure 2. The four inscribed miniature ingots from Enkomi, Cyprus, with their respective drawings (inv. nos. 53.2, 53.3, 1936-VI-19/1 and 1995, from top to bottom). Note that no drawing is available for no. 1995. Photograph adapted from Ferrara 2012. 


\begin{tabular}{|c|c|c|c|}
\hline $\begin{array}{l}\text { Miniature copper } \\
\text { ingot }\end{array}$ & $\begin{array}{l}\text { inv. 1936/Vi-19/1 } \\
\text { (Cyprus Museum) }\end{array}$ & $\# \# 174$ & A \\
\hline $\begin{array}{l}\text { Miniature copper } \\
\text { ingot }\end{array}$ & $\begin{array}{c}\text { inv } 53.2 \\
\text { (Cyprus Museum) }\end{array}$ & \#\#175 & $\begin{array}{c}H A \\
H \cap A\end{array}$ \\
\hline $\begin{array}{c}\text { Miniature copper } \\
\text { ingot }\end{array}$ & $\begin{array}{c}\text { inv. } 53.3 \\
\text { (Cyprus Museum) }\end{array}$ & \#\#176 & A \\
\hline $\begin{array}{l}\text { Miniature copper } \\
\text { ingot }\end{array}$ & $\begin{array}{c}\text { inv. } 1995 \\
\text { (Cyprus Museum) }\end{array}$ & ---- & $\begin{array}{c}\AA \\
\left(\text { rotated } 90^{\circ}\right)\end{array}$ \\
\hline Clay label & $\begin{array}{l}\text { RS } 94.2328 \\
\text { (Damascus } \\
\text { Museum) }\end{array}$ & $\# \# 210$ & $\| \wedge$ \\
\hline
\end{tabular}

Figure 3. Cypro-Minoan texts inscribed on the miniature ingots from Enkomi and on a clay label from Ugarit-Ras Shamra. 


\begin{tabular}{|c|c|c|c|c|}
\hline Object & Provenance & Cat. No. & Remarks on the inscriptions & Isolated sign \\
\hline Clay balls & Enkomi & \#\#002, \#\#018 & & $s^{t}$ \\
\hline Clay ball & Enkomi & $\# \# 004$ & & "yst \\
\hline Clay balls & Enkomi & $\# \# 006, \# \# 034, \# \# 072, \# \# 081$ & & A \\
\hline Clay ball & Enkomi & $\# \# 014, \# \# 057$ & & $\ddagger$ \\
\hline Clay balls & Enkomi & $\# \# 022,{ }^{*} \# 029$ & ${ }^{*}$ isolated at beginning of inscription & 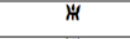 \\
\hline Clay ball & Enkomi & $\# \# 024$ & & $\bar{T}$ \\
\hline Clay balls & Enkomi & $\# \# 027, \# \# 051$ & & 0 \\
\hline Clay ball & Enkomi & \#041 & & r \\
\hline Clay balls & Enkomi & $\# \# 043, \# \# 075$ & & $t$ \\
\hline Clay ball & Enkomi & $\# \# 044$ & & Wi \\
\hline Clay balls & Enkomi & $\# \# 045, \# \# 046, \# \# 069, \# \# 083$ & & H \\
\hline Clay balls & Enkomi & \#\#048, \#\#052 & & $\Lambda$ \\
\hline Clay ball & Enkomi & \#\#049 & & 7 \\
\hline Clay ball & Enkomi & $\# \# 055$ & & 36 \\
\hline Clay ball & Enkomi & $\# \# 056$ & & Y \\
\hline Clay balls & Enkomi & $\# \# 058, \# \# 076$ & & ih \\
\hline Clay ball & Enkomi & $\# \# 059$ & & Wi \\
\hline Clay ball & Enkomi & $\# \# 061$ & & H \\
\hline Clay ball & Enkomi & $\# \# 067, \# \# 071$ & & $V$ and $U$ \\
\hline Clay balls & Enkomi & $\# \# 077, \# \# 089$ & & 面 \\
\hline Clay ball & Enkomi & $\# \# 078$ & restored division marker & $A \neq$ \\
\hline Clay balls and handle & Enkomi & $\# \# 082, \# \# 085, \# \# 120$ & & a \\
\hline Clay ostracon & Enkomi & $\# \# 093$ & & $\Psi$ and $\mathbb{A}$ \\
\hline Clay plaque & Enkomi & $\# \# 096$ & & $F \quad H$ \\
\hline Clay cylinder & Enkomi & $\# \# 097$ & 11. $5,6,7,8$ & $\rho^{f}, \neq, \neq, Y$ \\
\hline Amphora handle & Enkomi & $\# \# 121$ & & $A \cdot A \cdot n$ \\
\hline Jug handle & Kition & $\# \# 135$ & & A'in \\
\hline Jug handle & Kition & \#\#137 & & $A 18$ \\
\hline Jug handle & Kition & $\# \# 138$ & & $A^{\prime} \cdot$ \\
\hline Jug handle & Kition & $\# \# 139$ & restored division marker & A ['] 佂 \\
\hline Jug handle & Kition & $\# \# 142, \# \# 143, \# \# 147$ & & $A \cdot h$ \\
\hline Pithos rim & Kition & $\# \# 145$ & & $11 \operatorname{lng} 111$ \\
\hline Ivory pipe & Kition & $\# \# 161$ & at end of each line of inscription & $H$ and $\Lambda$ \\
\hline 'Votive kidney' & Kition & $\# \# 167$ & & $A \cdot Y$ \\
\hline Bronze obelos & Palaepaphos & $\# \# 171$ & uncertain reading & 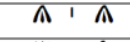 \\
\hline Copper ingot & Enkomi & $\# \# 174, \# \# 176$ & & 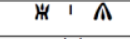 \\
\hline Bronze bowl & Cyprus & $\# \# 181$ & & int \\
\hline Bronze bowl & Enkomi & $\# \# 183$ & & $\mathrm{H}$ \\
\hline Bronze ring & Myrtou & $\# \# 184$ & isolated at beginning of inscription & int \\
\hline Stone block & Palaepaphos & $\# \# 189, \# \# 190$ & & 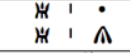 \\
\hline Pithos lid & Kalavassos & $\# \# 191$ & & 14 \\
\hline Tablet & Ugarit & $\# \# 215$ & & ひ电ま \\
\hline
\end{tabular}

Figure 4. Isolated signs in the Cypro-Minoan texts. 

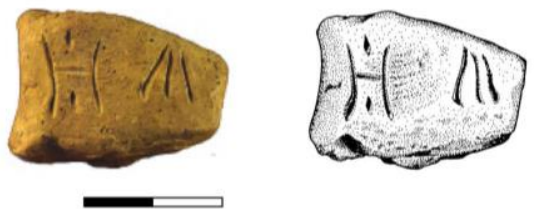

Figure 5. Cypro-Minoan label found at Ugarit (RS 94.2328), \#\#210. Photograph adapted from Ferrara 2012. 